\title{
ПРОБЛЕМА КЛІМАКТЕРІЮ У ПРАКТИЦІ СІМЕЙНОГО ЛІКАРЯ
}

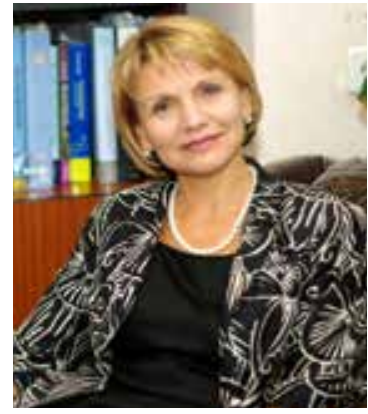

Т.Ф. ТАТАРЧУК

Д.мед.н., просресор, член-кор. НАМН України, заступник директора з наукової роботи, завідувач відділення ендокринологічної гінекології Інституту педіатрії, акушерства та гінекології НАМН України

\section{О.А. ЄФИМЕНКО}

к.мед.Н., старший науковий співробітник відділення ендокринологічної гінекології Інституту педіатрії, акушерства та гінекології НАМН України

\section{К.М. ДУБОВКА}

лікар-інтерн, НМАПО ім. П.Л. Шупика
2 міна демографрічної ситуації в економічно

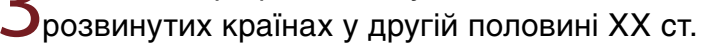
призвела до збільшення в популяції частки жінок старшої вікової групи. У даний час ці країни стоять перед серйозною соціальною і медичною проблемою - інверсією вікової піраміди. 3 кожним роком збільшується число жінок, які вступають у період менопаузи. Так, за даними ВООЗ, 10\% усього населення земної кулі становлять жінки в клімактеричному періоді. 3 одного боку, це пов язано зі збільшенням тривалості життя, з іншого - з раннім настанням клімактеричного періоду. Жінка понад третину свого життя знаходиться в стані дефіциту жіночих статевих гормонів. Відповідно питання якості життя в цей період стає дуже актуальним. У зв'язку зі збільшенням в нашій країні пенсійного віку для жінок на 5 років (до 60 років) питання профілактики і лікування клімактеричних розладів набуває особливої важливості. Крім того, тяжкі наслідки клімактеричних розладів у цьому віці погіршують якість життя жінки, впливають на ступінь працездатності, профресійні та інтелектуальні можливості [1].

Не дивлячись на те, що клімактерій не є захворюванням, він зумовлює порушення ендокринної рівноваги в організмі, що у свою чергу призводить до виникнення таких неприємних

\section{Старт} Харчування Фізична активність Спосіб життя Спостереження Інше

Об'ем

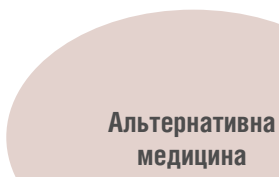

Режим

медико-соціальних заходів щодо захисту здоров'я, збереження працездатності і достойної якості життя жінок у пери- та постменопаузальному періодах [2].

Однак, на жаль, при появі вищезгаданих симптомів жінки перехідного віку порівняно рідко звертаються по допомогу до гінеколога і все частіше стають пацієнтками лікарів інших спеціальностей. У зв'язку з цим роль естрогенного дефріциту в патофрізіології системних змін при зазначених станах не завжди враховується належною мірою, що відображається на ефективності лікувальних заходів. Указані обставини диктують необхідність поширення відповідної інформації серед лікарів різного профрілю, які певним чином мають справу з проблемами патології жінок перехідного віку.

Визначення показань та вибір методу лікування клімактеричного синдрому (KC) здійснює лікар-гінеколог, а координуючу роль у забезпеченні профрілактичних і лікувальних потреб пацієнток, а також узгодження рекомендацій різних спеціалістів повинен виконувати сімейний лікар, оскільки саме він $є$ первинною ланкою при зверненні за медичною допомогою.

Надання первинної допомоги, лікування пацієнток на ранніх стадіях, координація діяльності вузьких фахівців, залучених до допомоги пацієнту, забезпечення безперервності надання медичної допомоги на тривалий час, організація необхідних оздоровчих та лікувальних заходів - це завдання лікарів загальної практики сімейної медицини (схема 1) [3].

Climax (клімактерій, клімакс, клімактеричний період) у перекладі з грецької означає сходи. Клімакс починається із завершення періоду репродуктивної активності, а всі етапи іїі згасання - сходинки, за якими здійснюється перехід до старості (схема 2). Це фрізіологічний перехідний період у житті жінки від репродуктивної фрази, що характеризується регулярними овуляторними циклами, до періоду згасання, а згодом і припинення менструальної та дітородної функцій. Протягом цього тривалого процесу відбувається поступове виснаження фролікулярного апарату яєчників, зниження їх функціональної активності, зміна гормональних взаємовідносин, розвиток гіпоестрогенії, ановуляції, результатом чого є настання менопаузи [1].

Розвиток КС зумовлюють як ендогенні, так і екзогенні чинники. До ендогенних чинників відносять вік, гормональні, гінекологічні та екстрагенітальні ендокринні порушення, ожиріння, хронічні соматичні захворювання, спадковість.

симптомів, як приливи, роздратованість, дисомнія, урогенітальні розлади, а також підвищує ризик розвитку остеопорозу та серцево-судинних захворювань (ССЗ). Усі ці дані свідчать про необхідність розробки цілої низки 


\section{ВІКОВІ ПЕРІОДИ ЖИТТЯ ЖІНКИ}
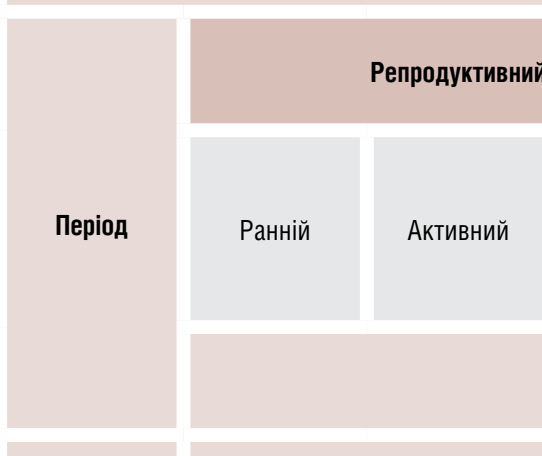

\section{ий}

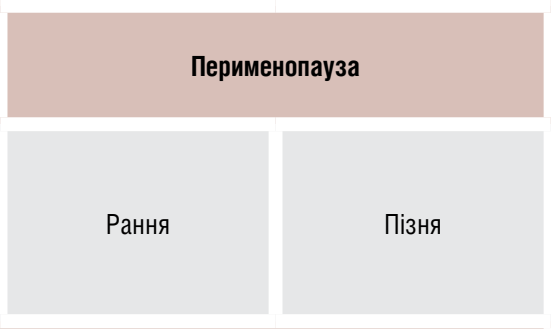

Перехідний

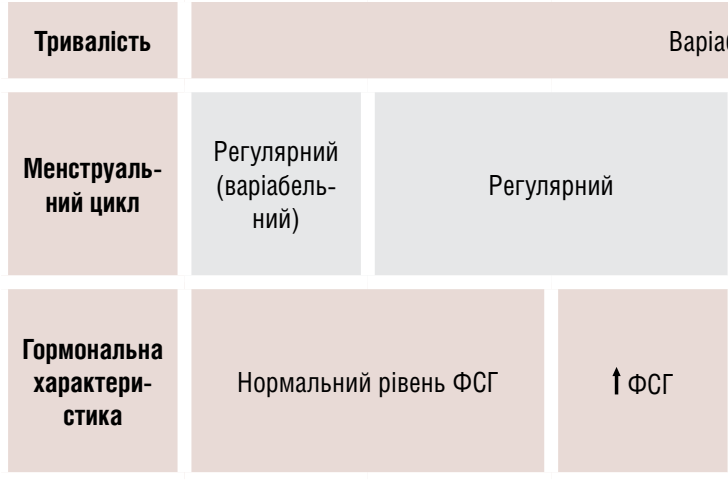

Екзогенними є соціально-економічні, стресові, поведінкові чинники тощо. Завдання сучасного лікаря - поліпшення якості життя цього вікового контингенту пацієнток і продовження їх фрізичного та інтелектуального довголіття [2].

Післярепродуктивний період життя жінки має відповідні стадії: менопаузальний перехід, пери- і постменопаузу.

Фізіологічний перебіг пременопуази спостерігається приблизно у 50\% жінок. При цьому порушення менструальної фрункції проявляється в поступовому збільшенні інтервалів між менструаціями до 40-90 днів і більше аж до менопаузи. Рідше спостерігаються мізерні менструації, що характеризуються поступовим зменшенням кількості крові до повного припинення кров'яних виділень.

Клінічно в період переходу до менопаузи виділяють чотири типи менструальних циклів:

क регулярні;

чергування регулярних циклів із затримками менструацій від декількох днів/тижнів до декількох місяців;

\% наявність олігоменореї (коротких менструацій);

(3 чергування періодів олігоменореї з дисфункціональними матковими кровотечами.

У пременопаузі у здорових жінок виражених гіпотрофрічних змін статевих органів не відмічається, але спостерігається поступово прогресуюча недостатність гормональної фрункції яєчників [1].

Зниження концентраціі естрогенів у периферичній крові призводить до змін у рецепторних тканинах, внаслідок чого клімактеричний період має свої характерні клінічні

особливості, які можна розділити на чотири групи.

Ранні симптоми - типові прояви КС, частота виникнення якого становить від 40 до 60\% випадків. Вони проявляються в основному в перименопаузальному періоді і включають:

\% нейровегетативні (вазомоторні) порушення - приливи жару, озноб, підвищена пітливість, головний біль, гіпотонія чи гіпертензія, тахікардія, посилене серцебиття;

(3) психоемоційні порушення - дратівливість, порушення сну (безсоння, сонливість), порушення уваги, слабкість, знервованість, неспокій, депресія, забудькуватість, неуважність, зниження лібідо.

Середньочасові симптоми - прояви, що виникають через 3-5 років після настання менопаузи (30-50\% випадків):

5 урогенітальні порушення - сухість слизової піхви, біль при статевому акті, свербіж і печіння у ділянці зовнішніх статевих органів, уретральний синдром, цисталгія, полакіурія, нетримання сечі, дизуричні явища;

s патологія шкіри та ії̈ придатків - сухість і втрата тургору шкіри, трофічні зміни, ламкість нігтів, випадіння волосся, поява зморщок, пігментних плям («плям старості»), сухий кон юнктивіт, стоматит, ларингіт, рожеві акне.

Пізні обмінні порушення - прояви, що виникають через 5-10 років постменопаузального періоду (25-40\%):

остеопороз - переломи хребців, шийки стегна і променевої кістки;

( СC3 - ішемічна хвороба серця (IXC), apтеріальна гіпертензія (АГ), інфраркти, інсульти. 
Дуже пізні порушення (5-12\% випадків):

5 хвороба Альцгеймера - емоційні порушення і порушення фрункції мислення (постменопаузальна депресія, деменція, меланхолія) [1].

За перебігом КС класифікують як:

3 типовий;

э ускладнений;

क атиповий.

При типовому перебігу симптоми КС виникають безпосередньо у період пременопаузи або у перші роки менопаузи.

Якщо в репродуктивному віці у жінки мав місце передменструальний синдром (ПМС), то можливе обтяження на $15 \%$ перебігу KC.

При ускладненій формі КС особливості клінічної симптоматики визначаються його поєднанням з екстрагенітальною патологією (АГ, гепатохолециститом, жовчнокам'яною хворобою, хронічним колітом, виразковою хворобою шлунка та дванадцятипалої кишки, сечокам'яною хворобою, цукровим діабетом). За рахунок екстрагенітальної патології посилюється тяжкість перебігу КС. У той же час КС обтяжує перебіг екстрагенітальної патології [4].

\section{РАННІ ПРОЯВИ КЛІМАКТЕРІЮ}

\section{Вазомоторні симптоми}

Такі симптоми зустрічаються у 60\% жінок. Із них найчастіше виявляються і асоціюються з клімактеричним періодом приливи жару до верхньої половини тулуба і голови, що тривають від кількох секунд до 30 хв і характеризуються підвищенням температури шкіри, розширенням периферичних судин, транзиторною тахікардією. Їх виникнення зумовлене конфліктом в гіпоталамо-гіпофрізарній системі. Гіпоестрогенія сприяє зміні регуляції центральних трансмітерів, відповідальних за діяльність центру терморегуляції в гіпоталамусі за участю адреналіну, норадреналіну, епінефрину, катехоламінів, ендорфінів, адренокортикотропного гормона. Протягом кількох секунд змінюється температура тіла, при цьому відбувається викид адреналіну, на 20 ударів підвищується частота серцевих скорочень, через 30 с змінюється рівень норадреналіну. Це призводить до розширення судин, збільшення кровонаповнення шкіри обличчя, рук, тулуба, що клінічно проявляється приливом жару. Затим включаються механізми потовиділення, охолодження, які можуть супроводжуватись ознобом, а в деяких випадках відбувається стиснення підшкірних вен, виникає піломоторна активація, тіло покривається «гусячою шкірою». Це так звані гіпоталамічні кризи. Окрім того, можуть спостерігатися парестезії, оніміння, закрепи, метеоризм [1].

За вираженістю і тривалістю змін вегетативних показників виділяють три типи приливів:

I - характеризується перевагою активації симпатикоадреналового відділу;

II - відзначається перевагою активації вагоінсулярного відділу;

III - вирізняється дисффункцією обох відділів.

Приливи виникають під дією чинників зовнішнього і внутрішнього середовищ, змінюючи активність центральних регуляторних систем. Це є результатом розбалансування діяльності ерго- і трофотропного відділів. Функція нейроендокринної системи під час приливу характеризується підвищенням рівнів адренокортикотропного, лютеїнізуючого (ЛГ) і тиреотропного (ТТГ) гормонів. Прилив - це прояв порушень у центральних механізмах, контролюючих синтез і пульсуюче вивільнення люліберину, тироліберину, кортиколіберину та інших нейропептидів і нейромедіаторів ЦНС, які беруть участь у регуляції як секреції тропних гормонів, так i найважливіших фрункцій (кардіоваскулярної, дихальної, терморегуляторної і психоемоційної) [5].

За результатами досліджень останніх років прилив жару супроводжується підвищенням рівня ЛГ та ТТГ за відсутності змін концентрації фролікулостимулюючого гормона (ФСГ), пролактину і тиреоїдних гормонів у плазмі перифреричної крові. У пацієнток із КС зберігаються добові ритми секреції ТТГ зі значним підвищенням його рівня у нічний час. Постійна підтримка високого рівня активних фракцій тиреоїдних гормонів сприяє підвищенню чутливості тканин до катехоламінів, що зумовлює характерні вазомоторні реакції. Відчуття жару виникає внаслідок центральної гіпертермії та проявляється через 30-60 с після спастичного стану в капілярах шкіри [1].

Для оцінки ступеня тяжкості КС використовують шкалу, засновану на кількості та інтенсивності приливів:

5) легкий ступінь КС - до 10 приливів на добу; загальний стан не порушений, працездатність збережена;

середній ступінь - від 10 до 20 приливів на добу; порушується загальний стан (запаморочення, погіршення пам'яті, порушення сну) і працездатність;

5 тяжкий ступінь - понад 20 приливів на добу; симптоматика різко виражена, працездатність частково або повністю втрачена [4].

KC може виникати в пременопаузальному періоді, з настанням менопаузи, а також протягом 1-5 років після менопаузи. Його типові симптоми проявляються в пременопаузі, якщо у пацієнтки в цьому періоді відзначається гіпоестрогенія. При гіперестрогенії перебіг КС нерідко спостерігається за типом клімактеричної кардіопатії. Він може виникати і на фроні збереженого ритму менструації у вигляді ПМС, який у жінок перехідного віку нерідко помилково розцінюється як клімактеричний. Тривалість захворювання в деяких випадках може сягати 10-15 років. Чим пізніше розпочате лікування, тим триваліше захворювання. Характерно, що у частини пацієнток КС виникає на фоні захворювань шлунково-кишково-печінкового комплексу (гепатохолецистит, жовчнокам'яна хвороба, хронічний коліт, виразкова хвороба шлунка та дванадцятипалої кишки). Установлено, що гастроінтестинальні пептиди (холецистокінін, вазоактивний інтестинальний поліпептид) синтезуються як в ЦНС, так і в шлунково-кишковому тракті (ШКТ). Цим зумовлене досить часте поєднання захворювань ШКТ і гіпоталамічних розладів.

У певної кількості хворих КС розвивається на фоні АГ, що передувала захворюванню протягом 5-6 років, причому в клінічній картині КС у пацієнток з АГ і атеросклерозом частіше переважає церебральний компонент (головний біль, зниження пам'яті, запаморочення). Деякі такі пацієнтки відзначають загострення АГ при КС у вигляді частих гіпертонічних кризів, лабільності артеріального тиску (АТ). АГ розвивається в осіб з вираженими ознаками дисфункції гіпоталамічних структур і ретикулярної фрормації мозку та проходить через стадію підвищення активності симпатико-адреналової системи на ранніх стадіях захворювання. При лабільній АГ без кризів в основному підвищується активність адреналової ланки, а при латентній АГ з кризами - як адреналової, так і медіаторної ланки. Відбувається порушення біосинтезу катехоламінів унаслідок зміни активності ферментів, що 
каталізують утворення і метаболізм амінів, а також порушення їхньої секреції і депонування. Ключовий момент у ланцюзі цих змін - зниження активності дофамінгідроксилази (перетворення дофраміну в норадреналін). Дофамін відіграє роль буфера, що стримує розвиток АГ. Здебільшого це спостерігається на ранніх стадіях захворювання, коли зберігається сприятлива дія дофаміну на ниркову гемодинаміку.

У порушенні нейрогуморальної регуляції серцево-судинної системи (ССC) важлива роль належить серотоніну і гістаміну. Дія цих речовин багатостороння і зумовлена їхнім впливом на вазомоторні центри і безпосередньо на гладку мускулатуру судин. Серотонін має сумарну пресорну дію, а гістамін належить до депресорних факторів, що викликають виражену дилатацію дрібних артеріол і венул.

У більшості пацієнток початку захворювання передують стресові ситуації різного характеру. При ускладнених формах КС тяжкість його збільшується за рахунок екстрагенітальної патології: частішають кризи при АГ, декомпенсованому цукровому діабеті, нападах жовчно- та сечокам'яної хвороб.

Перебіг КС може бути атиповим, за типом симпатикоадреналових кризів. Пароксизмальне підвищення АТ виникає за різних умов: як у спокої, так і в активному стані, при психічних порушеннях.

Клініка КС може характеризуватися появою кропив'янки, набряків на обличчі, вазомоторного риніту під впливом різноманітних фракторів, непереносимістю ряду лікарських препаратів, харчових продуктів, тобто симптомами, властивими алергічним процесам, які свідчать про зміну імунологічної реактивності з настанням менопаузи. Можуть також спостерігатися напади бронхіальної астми, які не піддаються традиційній терапії.

Виділена особлива фрорма КС, яка характеризується симпатико-адреналовими кризами, що виникають тільки в певні дні місяця, циклічними мігренеподібними станами. Аналіз тривалості менструальних циклів у репродуктивному віці і особливостей перебігу передменструальних періодів в останні 3-5 років до менопаузи свідчить, що у цих жінок до менопаузи мав місце ПМС.

Кризова фрорма ПМС має тенденцію до циклічного повторення в перші 1-4 роки після менопаузи. Така фрорма КС розглядається як трансформований ПМС. У цієї групи хворих менопауза настає після 50 років і пізніше, а в минулому у них спостерігалися гіперпластичні процеси в матці, мастопатія, затримка рідини і збільшення маси тіла в передменструальні дні.

До атипових фрорм КС належить клімактерична міокардіодистросрія, при якій відсутня залежність між вираженістю кардіалгії і даними електрокардіограми (ЕКГ), тобто при вираженому больовому синдромі зміни на ЕКГ незначні або відсутні. Також не виявлена залежність між змінами ЕКГ, порушенням працездатності та тривалістю захворювання.

Вегетативна нервова система у пацієнток із КС має свої особливості клінічної картини в залежності від типу вегетативних реакцій. При активації симпатико-адреналового відділу вегетативної нервової системи характерні: АГ, що розвинулася в перехідному періоді; почастішання пульсу та дихання у спокої; біль у ділянці серця. При функціональному переважанні парасимпатичного відділу вегетативної нервової системи виявляються гіпотензія, вагоінсулярні кризи за типом безсвідомих станів у задушливих приміщеннях, різноманітні алергічні про- яви, брадикардія. Клінічна картина приливу характеризується відчуттям завмирання серця, нестачі повітря, появою холодного поту, нудоти, запамороченням, різкою слабкістю.

При тривалому перебігу КС, особливо в поєднанні з АГ, що розвинулася в молодому віці, спостерігаються вегетосудинні розлади (симпатико-адреналові кризи, напади пароксизмальної тахікардії), психовегетативні порушення. Симптоми приливів характеризуються різноманітними проявами, відчуттям різкого дискомфорту і наявністю психоемоційних скарг (пацієнтка якби не може вийти з приливу).

У групі хворих з переважанням психоемоційних порушень (астенодепресивний і астеноневротичний синдроми) спостерігається підвищення активності функції кори надниркових залоз при незміненій секреції адренокортикотропного гормона. Рівні кортизолу, альдостерону та тестостерону значно підвищені. Позитивна проба з дексаметазоном і результати ультразвукового сканування дозволяють виключити анатомічні зміни в корі надниркових залоз.

Різноманітність клінічної картини КС свідчить про залучення до процесу різних структур диенцефальної ділянки та лімбіко-ретикулярного комплексу, який є результатом неадекватної адаптації старіючого організму до вікового зниження функції яєчників.

Зміна функціонального стану гіпоталамуса сприяє виникненню цілої низки ендокринно-обмінних і трофрічних порушень. У зв'язку з тим, що роль гіпоталамуса реалізується в тісному контакті зі структурами лімбічної системи та ретикулярної фрормації, які $є$ субстратом емоційної та мотиваційної поведінки, зміна їх функціонального стану слугує основою емоційно-психічних порушень: зниження пам'яті, уваги, погіршення працездатності, дратівливості, емоційної нестійкості. Функціональна неповноцінність вищих регуляторних центрів вегетативної нервової системи може бути результатом впливу ряду конституційно-генетичних факторів, несприятливого преморбідного фону (важкі умови життя, тривале голодування, тяжкі екстрагенітальні захворювання, черепно-мозкові травми, тривалі психотравмуючі ситуації) [1].

Для більшості пацієнток із КС характерні вегетативні розлади перманентного і пароксизмального характеру:

с стійкий червоний дермограсрізм;

поява червоних плям на шиї та грудях («судинне намисто»);

5 часті напади вираженого головного болю;

(5) тенденція до гіпотензії;

(5) пароксизмальне підвищення АТ в перехідному віці (46-52 роки);

к кризовий перебіг АГ;

s симпатико-адреналові кризи;

пароксизмальна тахікардія;

(5) вагоінсулярні кризи за типом вестибулярно-вегетативних нападів з яскраво вираженими психоемоційними порушеннями [3].

Установлено чітке порушення вмісту холестерину і тригліцеридів після менопаузи, особливо на фоні надлишкової маси тіла. Значне місце в клінічній картині захворювання посідають різні психоемоційні розлади. Здебільшого у жінок із КС вегетосудинні та психоемоційні розлади виникають одночасно. Зазвичай психоемоційні розлади з'являються перед менопаузою або протягом року після неї, у той же час як вазомоторні розлади часто стають домінуючими протягом року після менопаузи і тривають надалі в середньому до 5 років [1]. 
Психоемоційні порушення

Психоемоційні розлади зумовлені збільшенням кількості катехоламінів, які конкурують з катехолестрогенами за місце зв'язування в гіпоталамусі. При естрогенодефіциті, зниженні утворення $\beta$-ендорфінів у мозку порушується метаболізм серотоніну і норадреналіну, що призводить до розвитку тривожно-депресивних та іпохондричних станів.

У результаті вивчення клінічних особливостей динаміки невротичних і неврозоподібних симптомів у перехідному періоді жінки виділені наступні варіанти нервово-психічних розладів:

(3) астенічний;

(3) сенесто-іпохондричний;

3 тривожно-депресивний;

s істеричний [7].

Астенічний синдром характеризується слабкістю, втомлюваністю, дратівливістю, плаксивістю, підвищеною збудливістю, порушенням засинання та частими пробудженнями, головним болем, зниженням активності та працездатності, а також загального тонусу, порушенням концентрації уваги, забудькуватістю. При виникненні розладів сну (мають місце у двох третин жінок в клімактеричному періоді) відбувається посилений розпад медіаторів серотоніну та адреналіну, за рахунок чого знижується як загальна тривалість сну, так і відмічається недостатність фраз глибокого сну. Замість 4-6 фраз глибокого сну протягом ночі, необхідних для повноцінного відпочинку, є лише одна, або такі фрази взагалі відсутні. Внаслідок цього сон стає поверхневим, неглибоким, не приносить відпочинку.

Тривожні розлади - генералізована тривога (відчуття постійної напруги, передчуття чогось поганого), панічний розлад (напади інтенсивного страху, що повторюються та характеризуються різноманітними вегетативними проявами: серцебиттям, задухою, тремтінням, відчуттям запаморочення, пітливістю), фробії.

Депресивні розлади - ендогенні депресії (депресивні епізоди, рекурентні депресивні розлади або депресивні фрази біполярних розладів, що загострюються в даному періоді життя жінки), депресія як прояв розладу адаптації, депресія як прояв органічної патології головного мозку. Прояви депресивних розладів - знижений настрій; незадоволення; порушення сну, уваги, апетиту; суїцидальні тенденції; втрата ваги; безпідставні ідеї неспроможності; соматичні скарги. Однак при КС зазначені депресивні розлади не досягають психотичного рівня.

Істеричні порушення характеризуються поліморфною конверсійною симптоматикою: задухою, що часто імітує напад бронхіальної астми. Хворі відчувають несприйняття 3 боку близьких, що спричиняє посилення демонстрації їх хворобливого тяжкого стану. При цьому стані власне клімактеричні розлади ніби відходять на другий план, поступаючись місцем різним конверсійним та патохарактерологічним проявам. Додатковий вплив фракторів, навіть незначних, сприяє декомпенсації стану та зануренню у хворобу [6].

\section{Профрілактика і лікування}

Профрілактика і лікування вазомоторних розладів (за виключенням ЗГТ) включає в себе:

3 правильний режим праці та відпочинку;

s раціональне харчування (збагачена вітамінами їжа, переважання в раціоні овочів і фрруктів, жирів рослинного походження; виключення прянощів, кави, чаю, алкоголю, паління; обмеження продуктів, багатих на холестерин і жир); правильно підібраний комплекс лікувальної фізкультури;

5 використання фрізіотерапевтичних заходів - гідротерапія в домашніх умовах (контрастний душ, обливання, заспокійливі мелісові, шавлієві, хвойні ванни), бальнео-, аеро-, рефрлексотерапія, електросон, масаж, електрофорез;

3 негормональну медикаментозну терапію - прийом екстракту циміцифуги, що входить до складу препарату клімадинон [1].

Профілактика та лікування психоемоційних розладів

Окрім базової ЗГТ, психоемоційні розлади іноді потребують специфрічного лікування. Прерогатива у лікуванні таких хворих надається психіатрам.

3 Найбільш поширеною групою препаратів, що використовуються в даній ситуації, є антидепресанти. Засобами першої лінії вважаються селективні інгібітори зворотного захоплення серотоніну - флуоксетин, флувоксамін, серталін, пароксетин, есциталопрам, циталопрам; інгібітори зворотного захоплення серотоніну та норадреналіну - дулоксетин, венлафраксин, мілнаципран, агомелатин.

5 У важких випадках рекомендоване використання нейролептиків (френолон, трифтазин, метеразин, етаперазин), які переважно впливають на підкіркові структури ЦНС. Зазвичай лікування призначають з мінімальної дози препарату (1-2,5 мг), з можливим її підвищенням до 2-5 мг (френолон, трифртазин), 5-15 мг (метеразин), 2-8 мг (етаперазин). При отриманні клінічного ефекту дозу необхідно поступово знижувати. Тривалість курсу лікування становить 4-12 тиж.

Призначають транквілізатори: феназепам, сибазон по 5-10 мг 1-2 рази на добу.

(3 Можуть застосовуватися препарати, що містять барбітурати, і засоби, що впливають на вегетативні нервові центри (препарати беладонни).

- У комплексному лікуванні призначають фрітотерапевтичні та гомеопатичні засоби [6]

\section{СЕРЕДНЬОЧАСОВІ ПРОЯВИ КЛІМАКТЕРІЮ}

Розвиток середньочасових порушень відбувається протягом 2-3 років постменопаузального періоду. Цей час ще характеризується як прояв інтенсивного зовнішнього старіння, оскільки значно знижуються синтез колагенових і еластичних волокон у дермі, кількість і щільність фрібробластів у підшкірній клітковині. Ці процеси супроводжуються зменшенням пружності шкіри, появою зморщок, «плям старості»; збільшується ламкість нігтів, посилюється випадіння волосся. У цей час жінки піддаються більшому ризику розвитку грибкових і бактеріальних захворювань шкіри.

До середньочасових належать також урогенітальні порушення, які в клімактеричному періоді пов'язані з розвитком атрофрічних і дистрофрічних змін в естрогензалежних структурах нижньої третини сечостатевого тракту, що супроводжується зміною фракторів місцевого імунітету, приєднанням вторинної інсрекції (нерідко висхідної), що призводить до частого рецидивування і розвитку уретрального синдрому.

Висока чутливість нижніх відділів репродуктивної і сечовивідної систем до ендогенних і екзогенних естрогенів обумовлена їхньою ембріологічною спільністю - піхва, уретра, сечовий міхур і нижня третина сечоводів розвиваються з урогенітального синуса [4].

Як відомо, біоценоз піхви у жінок репродуктивного віку забезпечується лактобацилами, які перетворюють глюкозу в молочну кислоту. Остання утворюється з глікогену, що 
знаходиться в клітинах багатошарового плоского епітелію, які потрапляють після злущування у просвіт піхви. За рахунок цього рН піхвового вмісту знаходиться в межах 3,5-5,5. Лактобацили продукують інші антибактеріальні компоненти, включаючи перекис водню.

Лактобацили, низький рівень $\mathrm{pH}$, а також імуноглобуліни, що продукуються парауретральними залозами, та епітеліальні клітини, які піддаються циклічним процесам дозрівання, являють собою перші лінії місцевого імунітету слизової оболонки піхви. Інакше кажучи, всі ці фрактори є естрогенозалежними [5].

У пери- і постменопаузальному періодах на фоні дефіциту статевих стероїдів знижуються проліферативна активність епітеліальних клітин та продукція глікогену в клітинах. Кількість лактобацил значно зменшується чи взагалі зникає, внаслідок чого зростає $\mathrm{pH}$ піхвового секрету, що сприяє появі різноманітної аеробної і анаеробної фрлори, яка призводить до розвитку рецидивуючої вагінальної і сечової інфрекції [1].

Атрофрічні зміни в сечостатевій системі можуть підвищувати ризик розвитку генітального пролапсу, який істотно впливає як на фрізичне, так і на психічне здоров'я жінки і $\epsilon$ наслідком порушення фрункції м'язів тазового дна і неспроможності зв'язкового апарату матки і піхви [4].

\section{Лікування}

\section{Симптоматичне:}

与 цистрин (оксибутинін, оксибутин, дриптан, новітропан) М-холіноблокатор з прямою спазмолітичною дією, знижує тонус гладких м'язів матки, розслаблює детрузор сечового міхура, збільшує об'єм сечового міхура, знижує частоту скорочень детрузора та позиви до сечовипускання - дозою 2,5-5 мг 2-3 рази на добу. Курс лікування становить 3-6 міс.

与 убретид - інгібітор ацетилхолінестерази і псевдохолінестерази. Покращує нервово-м'язову передачу, підвищує тонус сечового міхура. Має більш тривалу дію, ніж неостигмін (прозерин). Доза препарату - 1 таблетка на добу, курс лікування -6 міс.

\section{Гормональна терапія}

При переважанні урогенітальних симптомів використовують чисті естрогени, а саме вагінальну форму естріолу, таку як препарат Овестин. Цей препарат має здатність специфрічно впливати на гормонозалежні структури нижніх відділів сечостатевої системи і по відношенню до ендометрія не має стимулюючих властивостей. Доза Овестину становить 0,5 мг для крему або 1 супозиторій 1 раз на добу на ніч упродовж 2-3 тиж, а потім у залежності від зменшення симптомів дозу знижують до 1 супозиторію 2 рази на тиждень.

Колпотрофін (проместрин) - синтетичний естроген з місцевою дією - призначають дозою 1 капсула на добу інтравагінально протягом 20 днів; крем застосовують перший тиждень 1 раз на добу, втираючи масажними рухами у слизову оболонку піхви та вульву, далі 1 раз кожні 2 доби протягом 3 тиж, до отримання ознак покращання.

Колпосептин містить проместрин та хлорхінальдол (антибіотик групи похідних хіноліну, має бактеріостатичну дію, при інтравагінальному введенні не абсорбується і не чинить резорбтивної дії). Доза препарату - інтравагінально 1 таблетка на ніч протягом 18 днів. Для прискорення ефекту можна вводити 1 таблетку 2 рази на день $\mathrm{i}$ збільшити тривалість лікування.
При використанні системної терапії, особливо в лікуванні жінок з пролапсом геніталій і тих, які готуються до оперативного втручання, окремою умовою є досягнення клінічного есректу. Його закріплення полягає в переході на симптоматичні лікарські засоби за 2-3 міс до операції з подальшим використанням гормональних препаратів в післяопераційному періоді [1].

\section{ПІЗНІ ПРОЯВИ КЛІМАКТЕРІЮ \\ Захворювання ССC}

ССЗ посідають одне з провідних місць серед причин захворюваності і смертності жінок в постменопаузальному періоді. Певна роль у розвитку цієї патології відводиться гіпоестрогенії. При КС частота виникнення гіпертензивних станів (як правило, АГ) зростає до 50-54\%, що в свою чергу істотно підвищує ризик розвитку IXC (більше ніж у 3 рази) та інсульту (більше ніж в 6-7 разів) [8].

Несприятливий вплив менопаузи на ризик виникнення захворювань серця, судин і в першу чергу IXC, зумовлені змінами в ліпідному спектрі крові, наявними в перехідному віці. Ці зміни відбуваються в так званому атерогенному напрямку і проявляються зниженням вмісту ліпопротеїнів високої щільності (ЛПВЩ), підвищенням рівня ліпопротеїнів низької щільності (ЛПНЩ) і холестерину. Крім того, виникнення і розвиток захворювань ССС у жінок в постменопаузі більшою мірою пов'язане з дефіцитом статевих гормонів. Доведено, що естрогени мають пряме відношення до захисного впливу на міокард і судини. У зв'язку з цим будь-які гіпоестрогенні стани призводять до розвитку несприятливих патологічних станів. Механізми здійснення такого впливу походять з відомих механізмів реалізації впливу естрогенів на СCC.

Ці механізми можуть бути умовно розділені на три групи. До першої групи належить механізм впливу на метаболізм ліпопротеїнів зі зниженням атерогенного профрілю. До другої - прямий вплив на рецептори до естрогенів, вазоактивні пептиди, простагландини, метаболізм сполучної тканини. До третьої - непрямий вплив на АТ, вуглеводний обмін.

Аналізуючи вплив естрогенів на механізм ліпопротеїдів, можна тезисно виділити, що в першому варіанті механізму впливу естрогенів спостерігається:

5 стимуляція утворення рецепторів до ЛПНЩ і прискорення розпаду часток ЛПНЩ і їх субфракцій;

3 зниження рівня загального холестерину;

підвищення рівня ЛПВЩ, переважно фракцій ЛПВЩ 2-3-го типу;

s зниження активності печінкової ліпопронеїнліпази і синтезу апопротеїду $A 1$;

s антиоксидантний ефект на ліпіди;

(3) посилення обміну ліпопротеїнів дуже низької щільності.

Серед механізмів дії естрогенів другої групи, пов'язаних із прямим впливом на рецептори до естрогенів, вазоактивних пептидів, простагландинів, обмінних процесів у сполучній тканині, існують наступні шляхи:

5 зниження резистентності судинного кровотоку;

\% підвищення індексів резистентності і пульсації судин;

зменшення вироблення тромбоксану;

3 збільшення секреції тромбоксану;

3 підвищення рівня релаксуючого фрактора ендотелію;

дія антагоніста кальцію. 


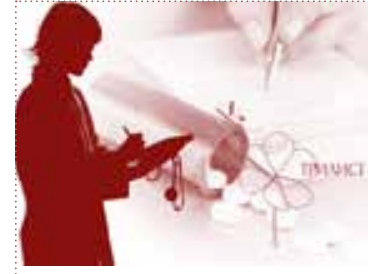

Визначення показань та вибір методу лікування КС здійснює лікар-гінеколог, а координуючу роль у забезпеченні просрілактичних і лікувальних потреб пацієнток, а також узгодження рекомендацій різних спеціалістів повинен виконувати сімейний лікар
Аналізуючи третій механізм дії естрогенів, пов'язаний з вуглеводним обміном, можна зазначити, що вони:

(3) підвищують чутливість до інсуліну;

збільшують секрецію інсуліну підшлунковою залозою;

3 зумовлюють нормалізацію тестів до глюкози;

3. знижують рівень вмісту глюкози.

Ожиріння, зміна дієтичних звичок та гіпокінезія у жінок постменопаузального віку сприяють появі таких метаболічних порушень, як зміна толерантності до глюкози та зниження чутливості до інсуліну.

Окрім усіх цих порушень, у жінок в менопаузі істотно змінюється і стан гомеостазу. Отже, можна говорити про посилення функціональної активності тромбоцитів та одночасної активізації відповіді ендотелію в осіб похилого віку чи про посилення ризику тромботичних процесів у судинах.

Також виявлена тенденція до посилення коагуляційного потенціалу крові: зменшується час згортання крові і рекальцифрікації плазми, підвищується рівень фрактора VIII, індекс гіперкоагуляції і тромбодинамічний індекс тромбоеластограми, який відображає посилення еластичних властивостей згустка крові. Таким чином, разом зі зниженням антикоагулянтного потенціалу в пери- і постменопаузі значно порушується і функція фрібринолітичної системи, що, з одного боку, також різко посилює ризик виникнення судинних захворювань, а з іншого - вказує на виснаження плазмової ланки, зокрема на зниження біосинтезу плазміногену в осіб похилого віку [9].

АГ ускладнює перебіг ССЗ у 50\% жінок. Особливості АГ у цьому віці визначають підвищення збудливості гіпоталамо-гіпофрізарних структур та активності симпатичної нервової системи. При дефіциті естрогенів порушується біосинтез і метаболізм катехоламінів, які чинять вплив на гладком'язові клітини судинної стінки і на активність ренін-ангіотензин-альдостеронової системи, яка є однією з ключових у регуляції АТ. Оскільки АГ є важливим фрактором ризику розвитку IXC, питання стосовно патогенетично обгрунтованого її лікування при KC набуває особливої актуальності.

Клінічні прояви клімактеричної кардіопатії та IXC мають багато спільного, що надзвичайно утруднює проведення диференційної діагностики цих захворювань. Особливі труднощі виникають при поєднанні клімактеричної кардіопатії та IXC, коли необхідно вирішувати питання щодо домінантної переваги того чи іншого процесу. Кардіалгія при клімактеричній кардіопатії, маючи певну схожість зі стенокардією, характеризується відмінними рисами. Найбільш істотною з них є тривалість больових відчуттів у ділянці серця (годинами, днями, тижнями, май- же постійно), в той час як біль при стенокардії характеризується короткочасністю (1-3 хв). Також відрізняється реакція хворих на фрізичні навантаження. На відміну від стенокардії, при якій фізичне навантаження провокує чи посилює больовий напад, при клімактеричній кардіопатії інтенсивність болю у ділянці серця при виконанні фрізичного навантаження не змінюється, а в деяких випадках зменшується, а інколи біль навіть зникає назовсім. Нарешті, має місце різна реакція хворих на лікарські засоби. Інтенсивність болю при стенокардії зменшується або біль зникає взагалі після прийому препаратів периферичних вазодилататорів, у той час як хворі на клімактеричну кардіопатію на ці лікарські засоби не реагують - для них ефективними є різні психоседативні препарати. Позитивні результати проб з фрізичним навантаженням у пацієнток із типовою стенокардією у 70-85\% випадків свідчать про атеросклеротичні зміни коронарних артерій серця. У хворих на атипову стенокардію проба з фрізичним навантаженням і результати коронарографії корелюють в меншій кількості випадків. Наявність поєднаної патології (клімактеричної кардіопатії та IXC) утруднюють діагностику, що потребує додаткового проведення коронарографії.

При клімактеричній міокардіодистрофії, яка належить до атипових форм КС, відсутня залежність між вираженістю кардіалгії і даними ЕКГ, зокрема при вираженому больовому синдромі зміни на ЕКГ незначні або відсутні. На ЕКГ характерним $є$ знижений ізоелектричний або навіть негативний зубець T; ST піднімається над ізолінією або спускається нижче неї. До цього приєднуються порушення провідності та реполяризації.

У діагностиці стану жінок в пери- і постменопаузі з точки зору визначення високого ризику розвитку ССЗ, в т.ч. IXC та інфраркту міокарда, крім дослідження вмісту ліпопротеїнів, холестерину, судинного кровотоку, необхідно використовувати і ряд додаткових досліджень. Вони включають динамічне вимірювання АТ на обох руках; періодичний запис ЕКГ; визначення вмісту глюкози і тест толерантності до глюкози; визначення рівня інсуліну в крові; дослідження біохімічних параметрів крові (лужної фоссратази, аланінамінотрансферази, аспартатамінотрансферази, креатиніну, холестерину, тригліцеридів); вивчення ліпідного спектра крові; визначення фракторів згортання крові, тромбоцитарного числа, вмісту простацикліну, тромбоксану; дослідження судинної резистентності і швидкості кровотоку в серцевому м'язі та сонній артерії за допомогою доплерометрії [10].

\section{Лікування АГ}

Беручи до уваги підвищення активності симпатичної нервової системи при КС, перспективною для його лікування може бути така тактика: інгібітор АПФ моексіприл 7,5-15 мг 1 раз на 
добу; інгібітор АПФ фозікард (фозіноприл) 10-20 мг 1 раз на добу; агоніст імідазолінових рецепторів моксонідин (тензотран, фрізіотенз) 0,2-0,4 мг/доб протягом 3 міс [8].

\section{ОСТЕОПОРОЗ}

Постменопаузальний остеопороз - системне захворювання, що характеризується зниженням кісткової маси після настання природної або штучної менопаузи на фоні вираженого тривалого дефіциту естрогену. Втрата кісткової маси у жінок в середньому становить близько $1 \%$ в рік і починається в основному після 3536 років. Цей процес значно прискорюється в перші роки постменопаузи, що є однією з причин підвищення в цей період частоти переломів кісток. Перебіг захворювання переважно $є$ безсимптомним, і нерідко питання щодо наявності остеопорозу виникає після перелому кісток. Остеопороз характеризується втратою кісткової маси, причому в першу чергу вражаються кістки з переважанням губчастої речовини: тіла хребців і дистальні відділи кісток передпліччя. Старечий остеопороз характеризується переважно ураженням трубчастих кісток кінцівок, що є причиною частого перелому шийки стегна [12].

Симптомами тривало існуючого і прогресуючого остеопорозу є: зменшення зросту, зміна постави, переломи, десрормація грудної клітки, біль у спині, утруднення дихання. Розрізняють первинний і вторинний остеопороз.

Первинний остеопороз існує у вигляді двох клінічних варіантів: постменопаузального і старечого (сенільного). Чинники ризику спадково зумовлені або пов'язані з особливостями сімейного анамнезу: літній вік, переломи в анамнезі, пізнє менархе і рання менопауза, порушення менструального циклу в репродуктивному віці за типом ановуляції, оліго- чи аменореї, безпліддя, більше трьох вагітностей і пологів, тривала лактація.

Вторинний остеопороз - захворювання мультифракторної етіології. Причинами цієї фрорми остеопорозу є ендокринні порушення (гіпо- або гіпертиреоз, цукровий діабет, гіперкортицизм), недостатність харчування і десріцит кальцію в харчовому раціоні, надмірне вживання алкоголю і кави (більше 5 чашок на день), паління, тривалий прийом кортикостероїдів, гепарину, протисудомних препаратів, ряд соматичних захворювань (хронічна ниркова недостатність, зниження абсорбції кальцію кишечником, гіподинамія).

Діагноз остеопорозу встановлюють на підставі даних анамнезу, визначення маси тіла і зросту. Визначення мінеральної щільності кісткової тканини проводиться за допомогою рентгенологічних методів (двохфотонна денситометрія, кількісна комп'ютерна томографрія). Звичайна рентгенографрія кісток, на жаль, дозволяє виявити зміни при втраті кіст- кової маси більше 30\%. Ультразвукова денситометрія п'яткової кістки має переваги при обстеженні жінок в постменопаузі. 3 лабораторних методів рекомендуються дослідження рівня кальцію/креатиніну, гідроксипроліну/креатиніну, піридоліну і дезоксипіридоліну в сечі. У крові визначають сироватковий остеокальцин, ізофрермент лужної фроссратази, проколагенові пептиди [13].

Головним завданням лікування остеопорозу $\epsilon$ уповільнення або припинення втрати маси кісток, запобігання новим переломам, нормалізація кісткового ремоделювання, зменшення больового синдрому, підвищення рухової активності, покращення якості життя.

До основних фрармакологічних препаратів для лікування і профрілактики остеопорозу належать препарати кальцію, вітамін D та його метаболіти, препарати антирезорбентної дії (кальцитонін, біфосфонати, ЗГТ) та стимулятори формування кісткової тканини (препарати фтору, іприфлавон, анаболічні стероїди, паратиреоїдний гормон).

Для жінок у постменопаузальному періоді норма добового споживання кальцію - 10001500 мг [11].

\section{ХВОРОБА АЛЬЦГЕЙМЕРА}

Хвороба Альцгеймера - часта причина деменції. Ії̈ першими симптомами $€$ зниження пам'яті на поточні події, неможливість запам'ятовувати і відтворювати нову інформацію, порушення розмовної мови та просторової орієнтації, зниження здатності до логічних суджень. При хворобі Альцгеймера в паренхімі головного мозку (переважно в ділянці гіпокампу і базальних ядер Мейнерта) між тілами нейронів утворюються ділянки, які складаються з ядра, представленого амілоїдним пептидом, оточеного відростками нервових клітин (з явищами вираженої дегенерації) [4].

Естрогени сприяють збереженню і регенерації нервових елементів в місцях найбільш виражених дегенеративних змін при хворобі Альцгеймера. Вони мають виражену нейротрофрічну дію на ділянку гіппокампу, яка найбільш страждає при цій хворобі, впливають на астроцити і гліоцити, що поліпшують функцію нейронів. Також мають антиоксидантну та протизапальну дію, покращують мозковий кровообіг і посилюють транспорт і метаболізм глюкози, що сприяє поліпшенню когнітивної функції, знижують підвищений рівень глюкокортикоїдів, викликаний стресом, при якому можливе ушкодження нейронів гіпокампу [14].

Деякі дослідники відмічають, що ЗГТ може знижувати ризик розвитку захворювання, а результати численних праць показують, що на фроні такої терапії хвороба Альцгеймера розвивалася на 35-60\% рідше, ніж у загальній популяції [5].

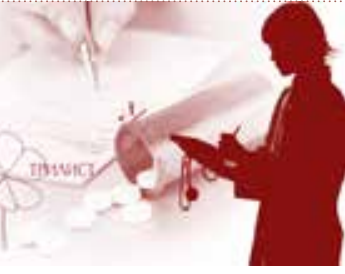

Застосування у ЗГТ комбінованих препаратів, що містять естрогени і прогестаген, у послідовному двосразному режимі є золотим стандартом лікування тяжких форм КС в перименопаузі 


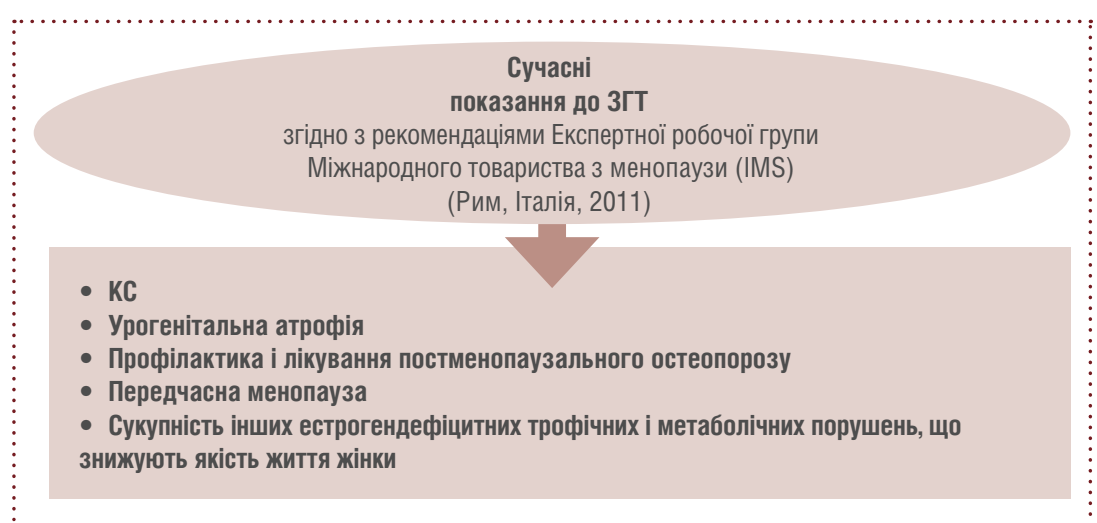

CXEMA 3.

ЗГТ ЯК ЗОЛОТИЙ СТАНДАРТ У ПРОФІЛАКТИЦІ ТА ЛІКУВАННІ КЛІМАКТЕРИЧНИХ РОЗЛАДІВ

\section{ЗАМІСНА ГОРМОНАЛЬНА ТЕРАПІЯ}

Сучасні вимоги та показання до застосування ЗГТ подані на схемах 3 і 4. У постменопаузі для ЗГТ використовуються натуральні естрогени з обов'язковим додаванням прогестагенів. До групи натуральних естрогенів належать естрадіол і його деривати; кон'юговані естрогени - естрону сульфрат, еквілін, еквілінін, естрону піперазин, естріолу сукцинат.

Естрадіол швидко всмоктується в ШКТ і, проникаючи в печінку, метаболізується, перетворюючись на естрон, кон'югати естрону та естрадіолу. Зв'язування та метаболічні перетворення естрогенів не знижують терапевтичного впливу, але для отримання максимального біологічного ефекту необхідно вводити досить високі дози гормона. Естрогени сприятливо впливають на ССС шляхом підвищення рівня ЛПВЩ і зниження концентрації атеро-

\section{Сучасні}

вимоги до ЗГТ

згідно з Міжнародним консенсусом Міжнародного товариства з менопаузи (2011)

- Ранній початок 3ГТ

- Натуральні компоненти 3Гт

- Прийом мінімально ефективних доз (початок застосування 3ГТ з низьких доз -

0,5-1 мг естрадіолу)

- Безперервний прийом естрогенів

- Диференційований підхід до вибору гестагенів (тривалість їх прийому не менше 14 днів)

CXEMA 4.

СУЧАСНІ ВИМОГИ ДО ЗГТ генних фрракцій ліпідів. При парентеральному призначенні естрогенів використовують різні способи введення: внутрішньом'язовий, черезшкірний (пластир), підшкірні імплантати, нашкірний (мазь). Парентерально введений естрадіол швидше досягає органів-мішеней і проявляє терапевтичний ефект дозою 0,05 мг/ доб, оскільки вимикається первинний метаболізм у печінці. Місцевий ефект для лікування урогенітальних порушень досягається також при вагінальному введенні естрогенів у вигляді мазі, свічок, кілець, песаріїв.

У даний час є загальноприйнятим положення щодо обов'язкового циклічного додавання до естрогенів прогестагенів протягом 14 діб, щоб уникнути розвитку гіперпластичних процесів в ендометрії [1].

Завдяки гестагенам відбувається циклічна секреторна трансорормація проліферуючого ендометрія і таким способом забезпечується його повне відторгнення. Прогестерон і його похідні пригнічують зв'язування естрогену в матці, знижуючи цитоплазматичну концентрацію рецепторів естрогенів [4].

У медичній практиці використовують прогестерон (прогестерон натуральний мікроіонізований) і два класи синтетичних прогестагенів - похідні прогестерону і 19-нортестостерону. Прогестерон і його похідні мають надзвичайно низьку андрогенну активність і практично не знижують сприятливого впливу гестагенів на ССС. Нове покоління прогестагенів (дезогестрел, гестоден, норгестимат) також не впливає і на обмін ліпопротеїнів.

Прогестагени можна призначати перорально в складі ЗГТ або парентерально (черезшкірно, вагінально - свічки, капсули). Для зниження частоти гіперплазії ендометрія більш важливою є тривалість прийому прогестагенів, ніж їхня щоденна доза. Низькі дози прогестагенів і циклічний прийом дозволяють звести до мінімуму їх негативний вплив на ліпопротеїни плазми [17].

Гормонотерапія протипоказана при пухлинах матки, яєчників і молочних залоз, маткових кровотечах неясного генезу, гострому тромбофрлебіті, гострій тромбоемболічній хворобі, тромбоемболічних порушеннях, зумовлених прийомом естрогенів, нирковій та печінковій недостатності, тяжких формах цукрового діабету [16].

Варто виявляти обережність під час проведення гормонотерапії за наявності захворювань з можливою затримкою рідини (астма, мігрень, епілепсія, АГ), а також при ендометріозі, безсимптомній міомі малих розмірів, депресії в анамнезі, нирковій недостатності.

Естрогенотерапію необхідно припинити з появою жовтяниці, при збільшенні розмірів матки. При матковій кровотечі слід провести діагностичне вишкрібання.

Перед призначенням ЗГТ необхідно провести дослідження: вивчення анамнезу з урахуванням численних протипоказань, УЗД геніталій, мамографія, цитологічне дослідження мазків, вимірювання АТ, дослідження фракторів коагуляції, рівня холестерину в крові.

Жінкам, які приймають гормональні препарати, необхідно кожні три місяці здійснювати контроль ефективності лікування і один раз на рік проводити УЗД геніталій, мамографрію та цитоморфологічне дослідження епітелію [16].

Застосування ЗГТ в лікуванні клімактерію 3 використанням комбінованих препаратів, які містять естрогени і прогестаген, у послідовному 


\begin{tabular}{|c|c|}
\hline Короткострокові цілі & Довгострокові цілі \\
\hline $\begin{array}{c}\text { Зменшення чи усунення приливів, пітливості, дратівливості } \\
\text { та інших проявів КС } \\
\text { Покращання стану шкіри, волосся, нігтів } \\
\text { Зниження частоти урогенітальних розладів }\end{array}$ & $\begin{array}{c}\text { Зниження АТ } \\
\text { Профрілактика IXC, інсульту } \\
\text { Зниження ризику і швидкості розвитку остеопорозу } \\
\text { Збереження інтелекту та пам'яті }\end{array}$ \\
\hline
\end{tabular}

двофразному режимі є золотим стандартом лікування тяжких форм КС в перименопаузі.

Препарати призначають переважно пацієнткам з інтактною маткою в пременопаузі, але їх можна застосовувати і в постменопаузі за усвідомленою згодою жінки. У більшості жінок на фоні двофразної терапії спостерігається менструальноподібна реакція.

Препарати, що містять антиандрогени (ципротерону ацетат), особливо показані пацієнткам з клімактеричними розладами і симптомами гіперандрогенії: жирною пористою шкірою, гірсутизмом і гіпертрихозом, зниженим тембром голосу.

У постменопаузі (після 2 років менопаузи) показані монофразні комбіновані препарати, що містять естрадіол іпрогестаген. Для лікування всього комплексу клімактеричних порушень і профрілактики остеопорозу застосовується препарат тиболон, який має тканинноспецифічні властивості. Тиболон чинить естрогенний вплив на ті органи і системи, де має місце дефіцит естрогенів, за відсутності характерного для естрогенів стимулюючого впливу на матку і молочні залози.

Монотерапія естрогенами рекомендується жінкам 3 видаленою маткою. Естрогени призначають в безперервному режимі [17].

Альтернатива ЗГТ може бути застосована при:

3 наявності протипоказань для ЗГТ;

(3)гативному ставленні пацієнтки до ЗГТ; раку молочної залози або геніталій.

У таких випадках призначають фрітопрепарати, що містять фрітоестрогени або інші рослинні екстракти з гормоноподібною дією (клімадинон, лайфремін, трибестан, кліварол, іноклін).

\section{ВИСНОВКИ}

Важливим контингентом обслуговування лікаря загальної практики сімейної медицини $є$ жінки віком від 40 років [3].

Перименопауза - один 3 найбільш важливих перехідних періодів у житті жінки, що вимагає до себе пильної уваги і грамотного лікарського супроводу. Крім того, більшість жінок хочуть у будь-якому віці виглядати елегантно і мають на це право, адже саме в період перименопаузи вони ведуть найбільш соціально активний спосіб життя. Проте в цей же час спостерігається маніфестна вегетосудинна і психоемоційна симптоматика, різної вираженості нейроендокринні, кардіоваскулярні, обмінно-метаболічні розлади, що здебільшого вимагає створення індивідуальних реабілітаційних програм і відповідної медикаментозної корекції.

Клімакс - це стан, що зобов'язує лікаря до особливого такту при спілкуванні з пацієнткою. Необхідно повною мірою проінформувати жінку про те, які будуть наслідки існуючої патології без застосування адекватної терапії і як може
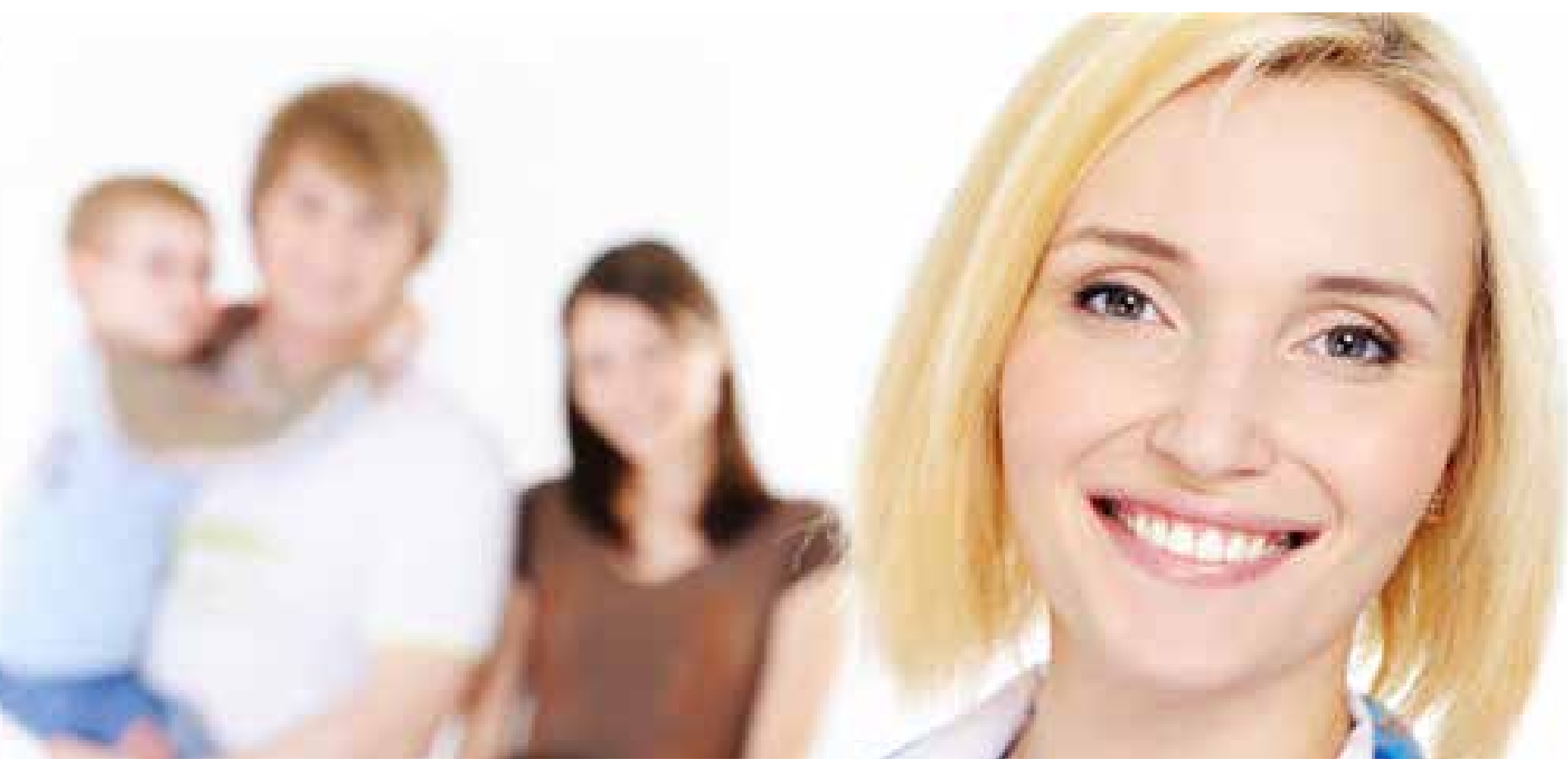
змінитися якість її життя при правильному лікуванні (таблиця). Профрілактика ускладнень повинна розпочинатись задовго до настання клімаксу [1].

Патологічний клімактерій $є$ однією з найважливіших медико-соціальних проблем сучасності. Підвищення середньої тривалості життя населення розвинутих країн світу призвело до зростання питомої ваги контингенту жінок віком від 40 років [5].

Таким чином, в період клімаксу на фоні зниження і виключення функції яєчників виникає ціла гама розладів. I хоча клімактерій не є захворюванням, він викликає порушення ендокринної рівноваги в організмі, що в свою чергу призводить до виникнення симптомів клімактеричного синдрому, згаданих вище. Серйозність наслідків менопаузи підкреслює особливу вагу своєчасних профілактичних заходів. Профрілактика КС повинна починатися задовго до перехідного віку жінки, оскільки розвиток і тяжкість перебігу КС залежать від резервних можливостей гіпоталамуса та соматичного стану [14].

Профрілактика КС включає: здоровий спосіб життя; відмову від шкідливих звичок; правильну організацію праці, відпочинку і харчування; профрілактику та своєчасне лікування захворювань різних органів і систем організму, які в поєднанні з КС мають особливість до взаємообтяження; своєчасне лікування ПМС, альгодисменореї та інших як гінекологічних, так і екстрагенітальних порушень. У профілактиці КС особливу увагу жінки слід звернути на регулярне статеве життя.

Численність клінічних проявів КС зумовлює значну потребу в лікувально-оздоровчих заходах [18].

Оскільки натепер первинною ланкою при зверненні за медичною допомогою є сімейний лікар, то він і повинен відігравати координуючу роль у забезпеченні профрілактичних і лікувальних потреб пацієнток та узгодженні рекомендацій різних спеціалістів для жінок в клімактеричному періоді. Разом із тим головним спеціалістом в лікуванні клімаксу є лікар-гінеколог [3].

Питання профрілактики і лікування ранніх і пізніх ускладнень постменопаузи залишаються одними з найбільш важливих у сучасній медицині, що зумовлено в першу чергу значним ростом числа осіб старших вікових груп в загальній популяції жіночого населення планети. Сьогодні можна зі значною вірогідністю стверджувати, що саме використання ЗГТ, яка визнана золотим стандартом лікування клімактеричних розладів, забезпечує позитивний вплив на якість життя жінок у пери- і постменопаузі, сприяє збереженню і поліпшенню їхньої працездатності. Це надзвичайно важливо, адже вік 40-55 років нині $€$ періодом досить високої професійної і соціальної активності [18].

\section{ЛІТЕРАТУРА}

1. Татарчук Т.Ф., Єфименко О.А.

Принципи діагностики, профілактики та лікування клімактеричних розладів // Журнал української лікарської еліти. - № 4 (10). - 2009. - С. 24-29.

\section{2. Тихомиров А.Л., Олейник Ч.Г.}

Патофизиология климактерия и новые возможности заместительной гормональной терапии у женщин в постменопаузе // Эндокринная гинекология. - 2007. - № 2 (8).
3. Abeer A. Al-Eassa, Abeer M. Al-Fadel, Maryam A. Al-Ajmi, Anwar A. Al-Najjar, Gamal M. Makboul, Medhat Elshazly

Knowledge and attitude of primary care doctors towards management of postmenopausal symptoms // Alexandria Journal of Medicine, Volume 48, Issue 2, April 2012, P. 167-173.

4. Bruce D., Rymer J.

Symptoms of the menopause // Best Practice \& Research Clinical Obstetrics \& Gynaecology, Volume 23, Issue 1, February 2009, P. 25-32.

5. Кулаков В.И., Сметник В.П.

Руководство по климактерию. - 2001.

6. David G. Weismiller.

Menopause // Primary Care: Clinics in Office Practice, Volume 36, Issue 1, March 2009, Р. 199-226.

7. Черниченко В.И., Губин В.А.

Психотерапия в коррекции психосоматического статуса при патологическом течении климактерического периода // Журнал неврологии и психиатрии им С.С. Корсакова. - 2006. - Т. 106, № 12. - С. 63-65.

8. Judd F.K., Hickey M., Bryant C.

Depression and midlife: Are we overpathologising the menopause? // Journal of Affective Disorders, Volume 136, Issue 3, February 2012, P. 199-211.

9. Иванова Л.Н.

Особенности течения сердечно-сосудистых заболеваний у женщин менопаузального периода с остеопенией // Сімейна медицина. - 2007. № 2 - C. 41-42.

\section{Bittner V.}

Menopause, Age, and Cardiovascular Risk: A Complex Relationship // Journal of the American College of Cardiology, Volume 54, Issue 25, 15-22 December 2009, P. 2374-2375.

11. Hutter R., Badimon J.J., Fuster V., Narula J.

Coronary Artery Disease in Aging Women: A Menopause of Endothelial Progenitor Cells? // Medical Clinics of North America, Volume 96, Issue 1, January 2012, P. 93-102.

12. Татарчук Т.Ф., Ефименко О.А.

Современные подходы к лечению постменопаузального остеопороза // Здоровье женщины. - 2011. - № 6 (62). - С. 18-22.

13. Татарчук Т.Ф.

Костная ткань и гормоны: остеопороз у женщин в постменопаузальном периоде в практике врача-гинеколога // Педіатрія, акушерство і гінекологія. - 2010. - № 1. - С. 48-49.

\section{4. Шуба H.M.}

Остеопороз - актуальная проблема XXI века: современное представление о патогенезе и терапии // Український ревматологічний журнал. 2008. - № 2. - C.5-14.

\section{Kaunitz A.M.}

Consequences of Early Menopause // Journal Watch Women's Health, 2012.

16. Татарчук Т.Ф., Єфіменко О.О., Мігайчук М.В.

Комплексна терапія гіперпластичних процесів ендометрія у жінок пізнього репродуктивного віку // Ліки України плюс. - № 3 (12). - 2010. C. 32-35.

17. Татарчук Т.Ф., Косей Н.В., Самосійна О.О., Зданович І.Є.

Можливості застосування гормональної терапії у лікуванні тяжкої форми клімактеричного синдрому у жінок з лейоміомою матки // Здоровье женщины. - 2010. - №. 6 (52). - С. 118-122.

\section{Kang J.H.}

Francine Grodstein. Postmenopausal hormone therapy, timing of initiation, APOE and cognitive decline // Neurobiology of Aging, Volume 33, Issue 7, April 2012, Pages 1129-1137.

19. Northrup $C$.

The Wisdom of Menopause (Revised Edition): Creating Physical and Emotional Health During the Change, March 2012. 